\title{
Originals
}

\section{The histopathology of the pancreas in Type 1 (insulin-dependent) diabetes mellitus: a 25-year review of deaths in patients under 20 years of age in the United Kingdom}

\author{
A. K. Foulis, C. N. Liddle, M. A. Farquharson, J.A. Richmond and R. S. Weir \\ Department of Pathology, Royal Infirmary, Glasgow, Scotland
}

Summary. A 25-year computerised survey of deaths in the United Kingdom among diabetic patients of 19 years of age and under was performed. Suitable pancreatic material was available in 119 out of the 498 identified patients. The duration of diabetes was known in 95 of the 119 patients. In 60 patients it had been present for less than 1 year. Insulitis was present in 47 of the 60 patients (78\%) with recent onset disease, and was also found in 3 patients who had been treated for diabetes for between 1 and 6 years. In cases in which it was identified, insulitis affected $23 \%$ of islets containing insulin, but af- fected only $1 \%$ of islets which were insulin deficient, thus supporting the concept that insulitis represents an immunologically mediated destruction of insulin secreting B cells. Four patients appeared to have a different disease from classical Type 1 (insulin-dependent) diabetes in that there was no evidence of insulitis and all islets contained insulin. The age of onset of diabetes was eighteen months or less in these patients.

Key words: Type 1 (insulin-dependent) diabetes, pancreatic pathology, insulitis, islets of Langerhans.
Insulitis (an inflammatory infiltrate affecting the islets of Langerhans) has been regarded as the characteristic lesion of recent onset Type 1 (insulin-dependent) diabetes mellitus [1]. However, its exact incidence has remained controversial because of the small number of cases reported in the literature. There are essentially only five histopathological studies of recent onset Type 1 diabetes in which significant numbers of cases have been included [1-5].

Insulitis was present in only 32 out of 73 patients included in these reports. There can be few other diseases as important to the community as Type 1 diabetes in which so little pathological material is available for study. In an attempt to partially rectify this situation, a computer survey of all deaths in diabetic patients under the age of 20 years in Scotland, England and Wales was commissioned.

\section{Subjects and methods}

The Scottish Hospital Inpatient Statistics have been computerised since 1961. These records, held by the Scottish Health Service Common Services Agency, code all hospital deaths and causes of death, and indicate whether an autopsy was performed. A listing was provided for the years 1961-1981 of all deaths from diabetes mellitus in patients under 20 years of age. Death certificates in England and Wales have been computerised by the Office of Population Censuses and Surveys, London, since 1959. Copies of death certificates recorded between 1959 and 1983 were provided of diabetic patients who had been autopsied and who were under 20 years of age. A separate manual survey of the autopsy records of the Royal Hospital for
Sick Children in Glasgow over a 60 -year period was also done. The pathology departments of the hospitals where these patients died were contacted. Where possible, blocks of pancreas and copies of autopsy reports and case records were provided.

Cases where there was significant pancreatic autolysis were rejected. Suitable blocks of pancreas were available from 14 patients who had died at the Royal Hospital for Sick Children, Glasgow, 21 of 49 patients identified from the Scottish computer survey, and 84 out of 435 deaths from the survey done in England and Wales. Thus, the total number of cases was 119 .

\section{Subjects}

The patients comprised 47 males and 72 females, with an age range from 3 months to 19 years. Case notes and autopsy records were not available in every case. The duration of diabetes was known in 95 patients; of these, it had been present for less than a year in 60 patients. The duration of diabetes in the remainder ranged from 1-14 years. Several patients were known clinically to have other diseases. Three suffered Down's syndrome, three had thyrotoxicosis, two had Addison's disease, two had muscular dystrophy, one had cerebral palsy, one was epileptic and one had a corrected Tetralogy of Fallot. The cause of death in patients with recent onset diabetes was given as complications of ketoacidosis in all cases except one. She was a 6-year-old with cerebral palsy who was admitted moribund in ketoacidosis but also had evidence of acute myocarditis at autopsy. Among the patients with prolonged duration diabetes (diabetes present for more than 1 year) the most common cause of death was still ketoacidosis. Other causes included hypoglycaemia ( 5 cases), lobar pneumonia ( 3 cases), tuberculosis, influenza pneumonitis and tetanus (1 case each).

\section{Methods}

Five micron serial sections were cut from all the formalin fixed paraffin embedded blocks of pancreas. Section one was stained by haema- 


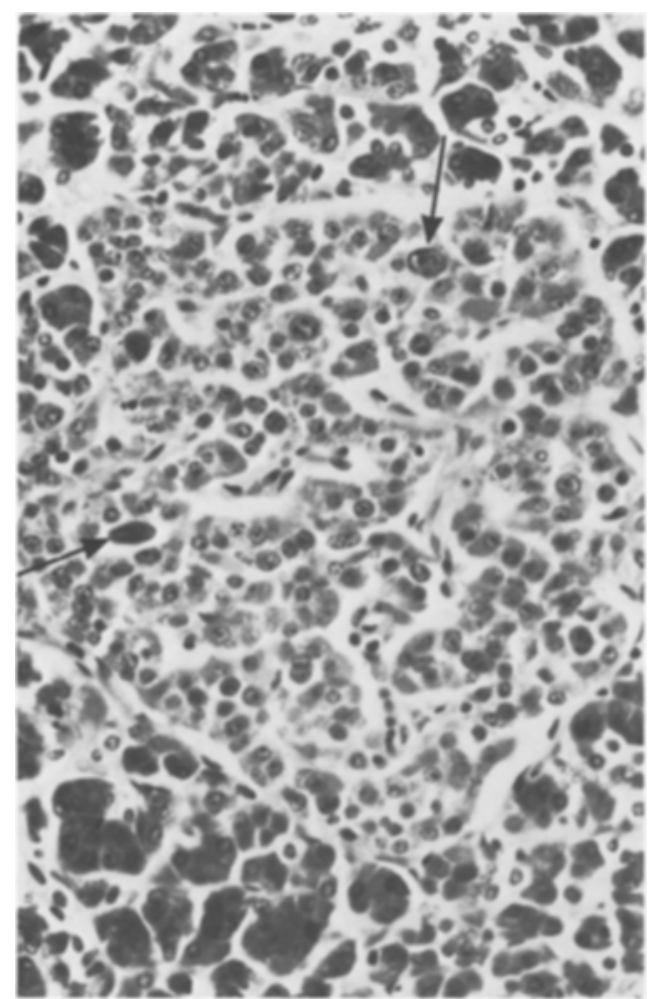

Fig. 1. A hyperplastic insulin containing islet (as revealed by immunohistochemistry on the adjacent serial section). Some endocrine nuclei are polyploid (arrows). There is no evidence of any destructive process (Haematoxylin and Eosin $\times 340$ )

toxylin and eosin. Sections two to six were stained by indirect immunoperoxidase techniques using the following primary antisera: guinea pig anti-insulin (Wellcome, Dartford, England), rabbit anti-glucagon (Guildhay, Guildford, England), rabbit anti-somatostatin (RIA UK Ltd., Tyne \& Wear, England), rabbit anti-pancreatic polypeptide (Metachem Diagnostics Ltd., Northampton, England), and mouse monoclonal antibody PD7/26, which is directed against the T 200 leucocyte common antigen present on all leucocytes [6] (gift from Dr. D. Y.Mason, Oxford, England). This last antibody was used as a sensitive marker for the presence of insulitis. The following bridges for the indirect techniques were used: peroxidase conjugated rabbit antiguinea pig, swine anti-rabbit and rabbit anti-mouse immunoglobulins (Dako, High Wycombe, England). The reactions were developed using diaminobenzidine as substrate.

Control pancreata and spleens from children who had died over a 50 -year period of diseases unrelated to either organ were studied. There was no evidence that prolonged storage of paraffin embedded blocks of tissue altered the ability to stain pancreatic hormones or the T 200 leucocyte common antigen immunohistochemically.

Detailed morphometric studies of the relative numbers of islet endocrine cells were not done.

\section{Statistical analysis}

The proportion of insulin containing islets affected by insulitis in the 50 patients with known duration of diabetes and insulitis was compared to the proportion of insulin deficient islets thus affected. Statistical significance was assessed using the Chi-squared test.

\section{Results}

\section{Islet pathology in recent onset Type 1 diabetes}

In most cases there appeared to be essentially three populations of islet. Firstly, insulin containing islets un-
Table 1. Insulin content of islets in relation to insulitis in 50 patients with Type 1 diabetes of known duration

\begin{tabular}{|c|c|c|c|c|c|c|}
\hline Sex & Age & $\begin{array}{l}\text { Duration of } \\
\text { symptoms }\end{array}$ & $\begin{array}{l}\text { No. of } \\
\text { ICI }\end{array}$ & $\begin{array}{l}\text { No. of } \\
\text { ICI with } \\
\text { insulitis }\end{array}$ & $\begin{array}{l}\text { No. of } \\
\text { IDI }\end{array}$ & $\begin{array}{l}\text { No. of } \\
\text { IDI with } \\
\text { insulitis }\end{array}$ \\
\hline $\mathbf{F}$ & 18 months & 1 week & 90 & 72 & 1239 & 3 \\
\hline $\mathrm{F}$ & 21 months & 2 weeks & 19 & 12 & 100 & 2 \\
\hline $\mathrm{F}$ & 2 years & 1 week & 140 & 23 & 366 & 2 \\
\hline $\mathrm{F}$ & 2 years & 2 weeks & 1 & 1 & 160 & 5 \\
\hline M & 2 years & 2 weeks & 19 & 2 & 224 & 0 \\
\hline$F$ & 3 years & 3 weeks & 153 & 69 & 46 & 1 \\
\hline $\mathrm{F}$ & 3 years & 6 weeks & 87 & 23 & 66 & 1 \\
\hline M & 3 years & 1 week & 23 & 5 & 191 & 1 \\
\hline $\mathbf{M}$ & 3 years & 3 months & 41 & 7 & 82 & 1 \\
\hline $\mathrm{F}$ & 4 years & 3 weeks & 133 & 66 & 121 & 14 \\
\hline $\mathbf{M}$ & 4 years & 3 weeks & 131 & 4 & 227 & 2 \\
\hline M & 5 years & 1 week & 66 & 10 & 457 & 6 \\
\hline $\mathrm{F}$ & 5 years & 3 months & 22 & 5 & 5 & 0 \\
\hline $\mathrm{F}$ & 6 years & 3 weeks & 41 & 1 & 63 & 0 \\
\hline $\mathrm{F}$ & 6 years & 1 week & 30 & 4 & 79 & 1 \\
\hline M & 6 years & 1 week & 114 & 64 & 375 & 8 \\
\hline$F$ & 6 years & 5 weeks & 2 & 2 & 83 & 0 \\
\hline $\mathbf{M}$ & 6 years & 9 months & 8 & 6 & 221 & 0 \\
\hline $\mathbf{M}$ & 7 years & 1 week & 43 & 25 & 140 & 6 \\
\hline $\mathrm{F}$ & 7 years & 1 week & 71 & 10 & 101 & 1 \\
\hline $\mathrm{F}$ & 8 years & 3 weeks & 120 & 9 & 99 & 0 \\
\hline $\mathbf{M}$ & 8 years & 2 weeks & 3 & 2 & 65 & 0 \\
\hline $\mathrm{F}$ & 8 years & 1 week & 141 & 41 & 123 & 2 \\
\hline M & 8 years & 3 months & 72 & 4 & 69 & 0 \\
\hline$F$ & 9 years & 2 years & 2 & 1 & 22 & 0 \\
\hline$F$ & 10 years & 6 weeks & 5 & 4 & 176 & 0 \\
\hline M & 10 years & 3 weeks & 165 & 5 & 392 & 1 \\
\hline $\mathbf{M}$ & 11 years & 4 weeks & 19 & 2 & 167 & 1 \\
\hline$F$ & 11 years & 1 week & 16 & 15 & 66 & 2 \\
\hline $\mathbf{M}$ & 11 years & 6 years & 14 & 1 & 267 & 0 \\
\hline M & 12 years & 2 weeks & 75 & 2 & 190 & 0 \\
\hline $\mathrm{F}$ & 12 years & 2 months & 129 & 32 & 37 & 2 \\
\hline $\mathrm{F}$ & 12 years & 2 months & 50 & 30 & 55 & 2 \\
\hline F & 12 years & 1 month & 176 & 24 & 99 & 0 \\
\hline $\mathrm{F}$ & 12 years & 3 weeks & 39 & 11 & 45 & 3 \\
\hline M & 13 years & 2 weeks & 76 & 11 & 71 & 2 \\
\hline $\mathrm{F}$ & 13 years & 3 months & 15 & 3 & 79 & 0 \\
\hline$F$ & 13 years & 1 week & 84 & 5 & 26 & 0 \\
\hline M & 13 years & 1 week & 45 & 5 & 72 & 0 \\
\hline$F$ & 14 years & 1 week & 247 & 24 & 56 & 0 \\
\hline $\mathrm{F}$ & 14 years & 1 week & 36 & 7 & 139 & 1 \\
\hline $\mathbf{M}$ & 15 years & 6 months & 60 & 17 & 290 & 4 \\
\hline M & 16 years & 4 months & 134 & 30 & 267 & 0 \\
\hline M & 17 years & 1 week & 420 & 83 & 171 & 16 \\
\hline M & 17 years & 1 week & 182 & 79 & 291 & 0 \\
\hline $\mathrm{M}$ & 17 years & 1 week & 58 & 7 & 27 & 0 \\
\hline $\mathrm{F}$ & 18 years & 3 weeks & 157 & 3 & 5 & 0 \\
\hline $\mathrm{F}$ & 18 years & 1 week & 107 & 4 & 10 & 0 \\
\hline $\mathrm{F}$ & 18 years & 3 weeks & 34 & 15 & 68 & 3 \\
\hline \multirow[t]{2}{*}{$\hat{F}$} & 19 years & $11 / 2$ years & 16 & 2 & 102 & 0 \\
\hline & & & 31 & 889 & 7892 & 93 \\
\hline
\end{tabular}

ICI $=$ insulin containing islets; IDI $=$ insulin deficient islets. $\%$ of ICI with insulitis $=23 \% ; \%$ of IDI with insulitis $=1 \% ; \%$ of islets that contain insulin $=33 \% ; \%$ of islets affected by insulitis $=8.3 \%$

affected by any destructive process or inflammation; secondly, insulin containing islets in which there was an inflammatory cell infiltrate (insulitis) and thirdly, insulin deficient islets. The proportions of these different islets varied from case to case in 50 patients with insulitis and a known duration of diabetes (Table 1 ). 

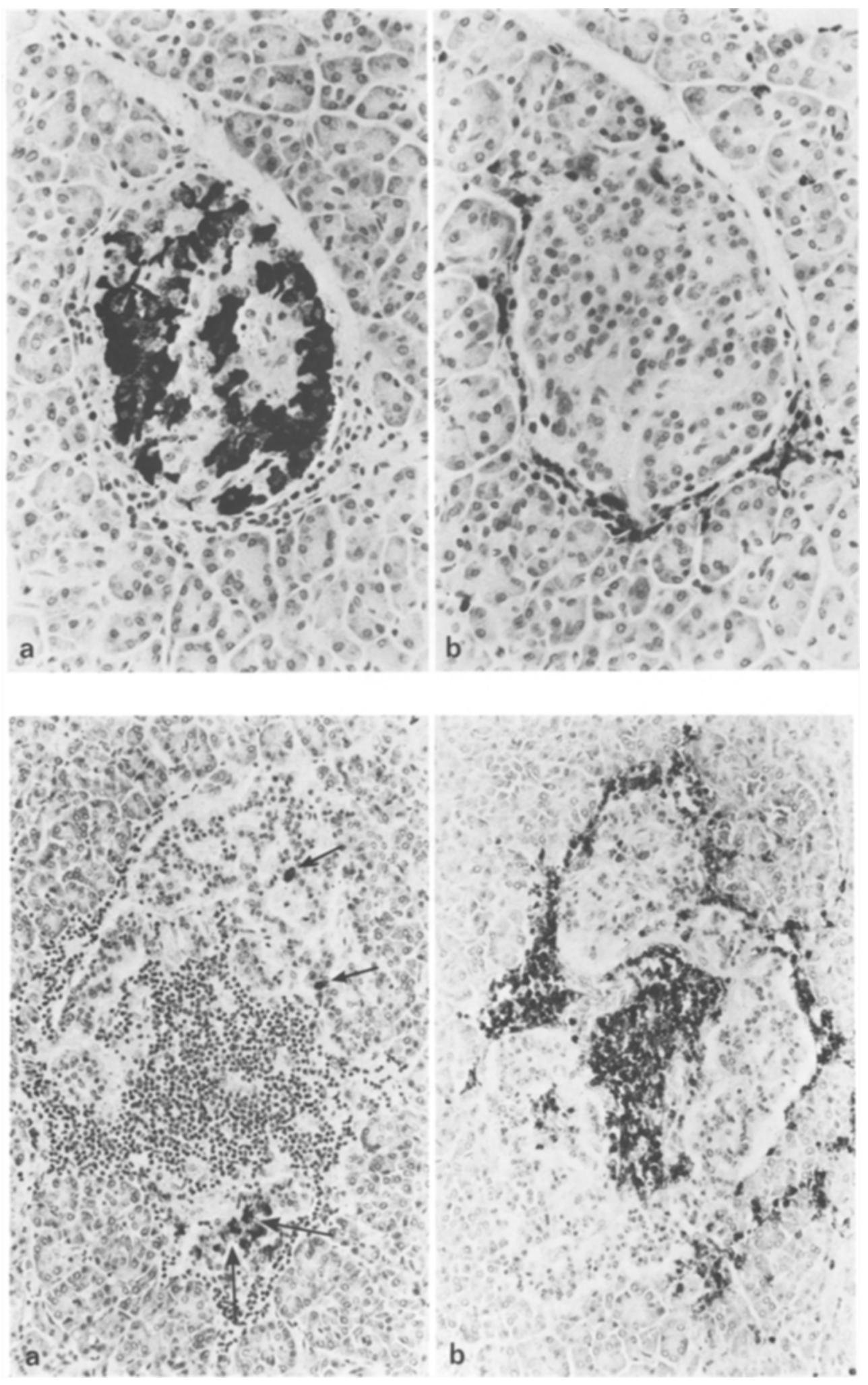

Fig. $2 \mathrm{a}$ and b. Early insulitis.

a There is relatively good preservation of B cells. b Characteristic peripheral infiltrate of chronic inflammatory cells. (a indirect immünoperoxidase for insulin; $\mathbf{b}$ indirect immunoperoxidase for $\mathrm{T} 200$ leucocyte common antigen, $\times 250$ )
Fig. 3a and b. Advanced insulitis. There is a dense lymphocytic infiltrate and relatively few B cells (arrowed) (a indirect immunoperoxidase for insulin; $b$ indirect immunoperoxidase for $\mathrm{T} 200$ leucocyte common antigen $\times 160$ )
An islet was defined as containing insulin after positive staining of endocrine cells with the anti-insulin antibody on one section. Islets were defined as free of insulitis when no lympoid cells were seen on the six serial sections, paying particular attention to the section stained for T 200 common leucocyte antigen. This proved useful in discriminating doubtful cases. Insulincontaining islets unaffected by insulitis usually appeared normal. However, some had a reduced proportion of B cells, and in many pancreata some were distinctly hyperplastic and contained polyploid B cells (Fig. 1). 


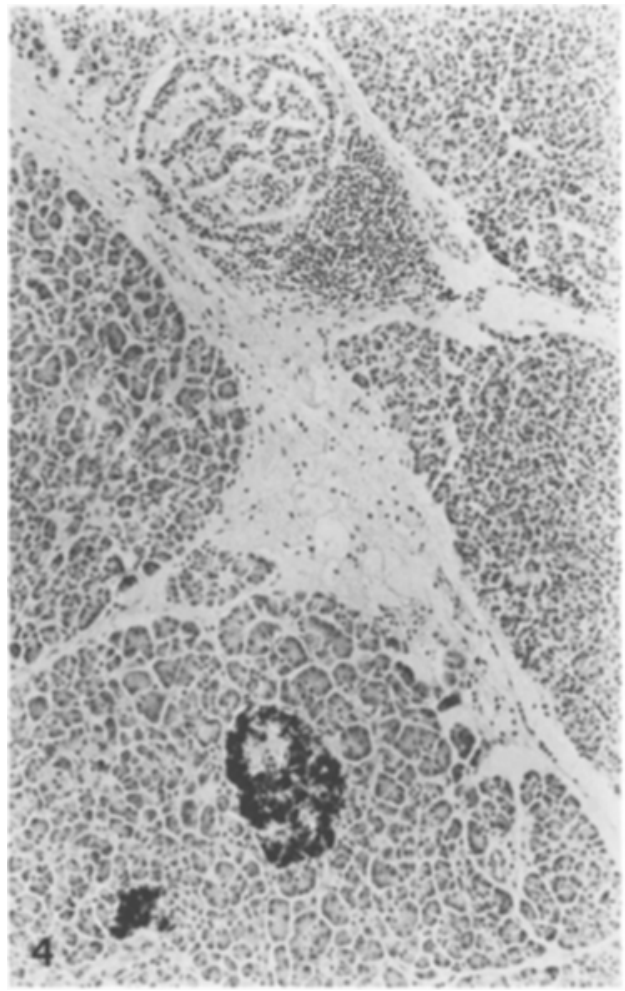

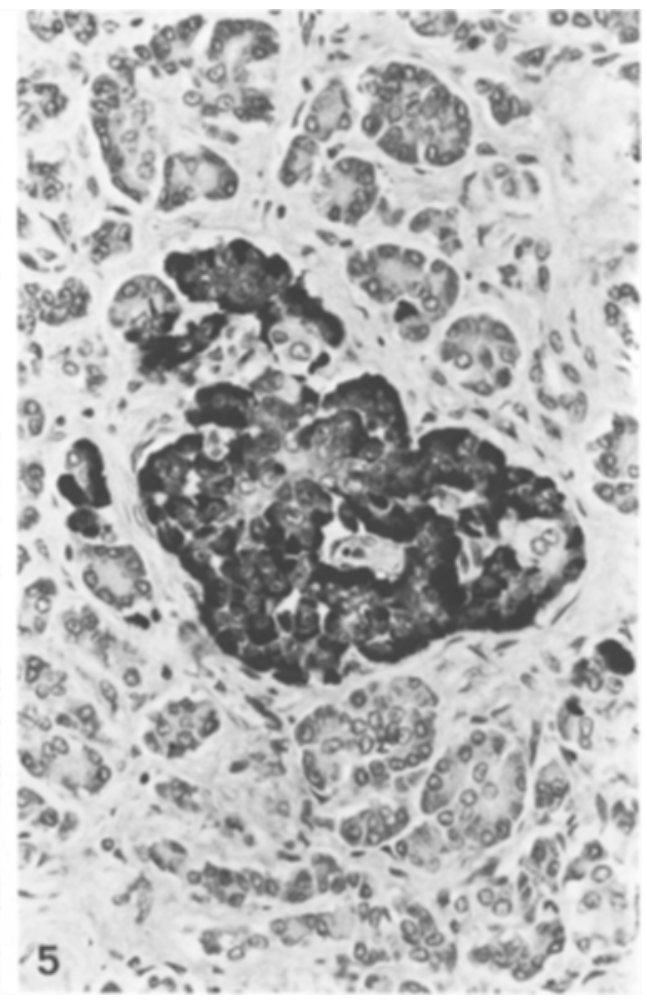

Fig.4. Residual inflammatory cells surround an insulin deficient islet (top of picture). Two unaffected insulin containing islets are present below it (indirect immunoperoxidase for insulin $\times 80$ )

Fig.5. Insulin deficient islet (as shown by serial sections) from a patient with prolonged duration Type 1 diabetes. Note that the pattern of distribution of A cells within the islet is relatively normal (indirect immunoperoxidase for glucagon $\times 260$ )
Table 2. Presence of insulitis in 60 patients with recent onset Type 1 diabetes

\begin{tabular}{lllllll}
\hline Age (years) & 1 year & $\begin{array}{l}1-2 \\
\text { years }\end{array}$ & $\begin{array}{l}3-5 \\
\text { years }\end{array}$ & $\begin{array}{l}6-9 \\
\text { years }\end{array}$ & $\begin{array}{l}\text { 10-14 } \\
\text { years }\end{array}$ & $\begin{array}{l}\text { 15-19 } \\
\text { years }\end{array}$ \\
\hline $\begin{array}{l}\text { Insulitis } \\
\text { present }\end{array}$ & - & 5 & 8 & 11 & 15 & 8 \\
$\begin{array}{l}\text { Insulitis } \\
\text { absent }\end{array}$ & $2^{\mathrm{a}}$ & $1^{\mathrm{a}}$ & - & - & $3^{\mathrm{b}}$ & $7^{\mathrm{c}}$ \\
\hline
\end{tabular}

a All islets in these cases contained insulin; ${ }^{b}$ in one case all islets were insulin deficient; ${ }^{c}$ in two cases all islets contained insulin; in one all islets were insulin deficient

Table 3. Eight patients with Type 1 diabetes for longer than 1 year in whom insulin containing islets were present

\begin{tabular}{lllrlrl}
\hline Sex & Age & $\begin{array}{l}\text { Duration of } \\
\text { disease }\end{array}$ & $\begin{array}{l}\text { No. of } \\
\text { ICI }\end{array}$ & $\begin{array}{l}\text { No. of } \\
\text { ICI with } \\
\text { insulitis }\end{array}$ & $\begin{array}{l}\text { No. of } \\
\text { IDI }\end{array}$ & $\begin{array}{l}\text { IDI with } \\
\text { Insulitis }\end{array}$ \\
\hline F & 13 months & 13 months & 603 & 0 & 0 & 0 \\
F & 9 years & 2 years & 2 & 1 & 22 & 0 \\
M & 11 years & 6 years & 14 & 1 & 267 & 0 \\
F & 15 years & 2 years & 104 & 0 & 63 & 0 \\
F & 16 years & 4 years & 17 & 0 & 142 & 0 \\
F & 17 years & 3 years & 62 & 0 & 44 & 0 \\
F & 18 years & 9 years & 42 & 0 & 180 & 0 \\
F & 19 years & 11/2 years & 16 & 2 & 102 & 0 \\
\hline
\end{tabular}

$\mathrm{ICI}=$ insulin containing islets; $\mathrm{IDI}=$ insulin deficient islets

Insulitis particularly affected islets containing insulin and there appeared to be a spectrum of histological appearances, suggesting progressive destruction of the $B$ cells within the islet (Table 1). In early insulitis there characteristically was infiltration by small lymphocytes at the periphery of an insulin containing islet (Fig.2). The number of B cells at this stage often appeared relatively normal. In the next stage there was a more diffuse inflammatory cell infiltrate within the islet, accompanied by a marked drop in the number of B cells (Fig.3). Occasionally islets in which no insulin-containing cells could be detected were also affected (Fig. 4). This probably represented the end stage of the destructive phase. The majority of inflammatory cells appeared to be small lymphocytes. Occasionally polymorphs were present, but plasma cells were not seen.

An islet was defined as insulin deficient if no endocrine cells were stained with the anti-insulin antibody on one section. All the endocrine cells in these islets appeared to stain if anti-glucagon, anti-somatostatin and anti-pancreatic polypeptide sera were applied simultaneously, indicating that there was not a population of cells containing a fourth hormone, and that totally degranulated B cells were not present. Insulin deficient islets formed the majority of islets in most recent onset cases. While these islets were easily recognisable as being abnormal, the sinusoids of islets in the glucagon rich lobe still appeared to be lined by A cells (Fig. 5), and the vascular connections to the exocrine tissue appeared unaffected. No detailed morphometric analysis was done, but the relative distribution of A, D and PP cells in these islets did not appear to be disturbed.

Insulitis was present in 64 out of the total of 119 cases. Among the 60 patients with known recent onset disease, it was present in $47(78 \%)$. In cases where insulitis was present, it affected $23 \%$ of islets containing insulin but only $1 \%$ of islets which were insulin defi- 

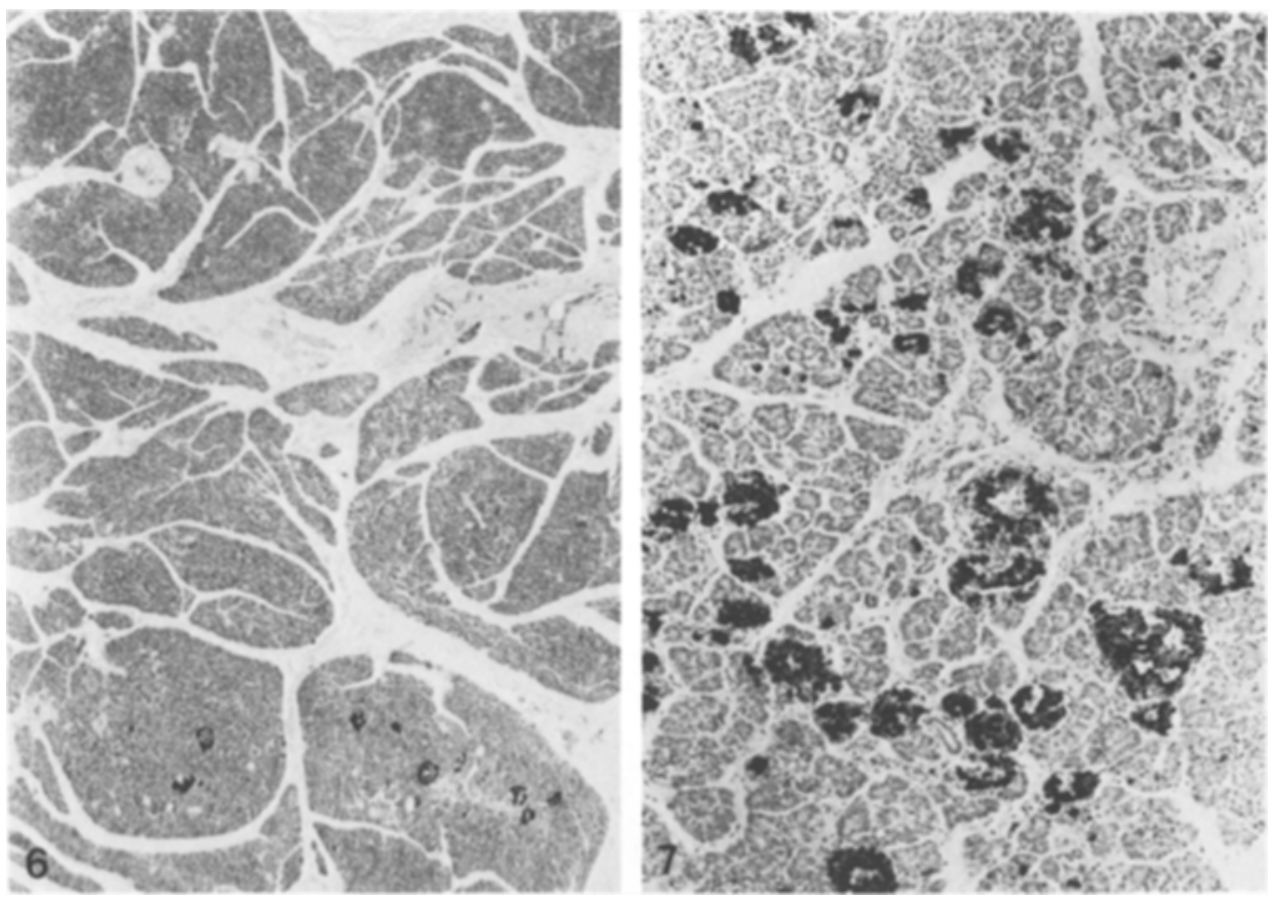

Fig. 6. Residual insulin containing islets (bottom of picture) distributed non randomly (indirect immunoperoxidase for insulin $\times 16$ )

Fig. 7. 3-month-old male infant with a 1-week history of diabetic symptoms. There is no evidence of a deficiency of B cells or insulitis (indirect immunoperoxidase for insulin $\times 65$ )

cient. ( $p<0.001$, chi squared test) (Table 1). While acknowledging that there must be considerable sampling error, there was a tendency towards a greater proportion of insulin containing islets being affected by insulitis in younger patients. Thirty-seven percent of insulin containing islets were affected in children of 3 years and under, while $18 \%$ were affected in patients aged 14-18 years (Table 1 ).

Table 2 gives the incidence of insulitis in patients who had diabetes for less than a year. From this it can be seen that, among the very young and among older diabetic patients, insulitis was less likely to be found.

\section{Islet pathology in patients with prolonged duration Type 1 diabetes}

Thirty-five patients were known to have had diabetes for more than a year. In 27 patients all islets appeared to be insulin deficient. Insulin-containing islets were found in the remaining 8 patients and three of these patients, who had been treated with insulin for $1 \frac{1}{2}$ years, 2 years and 6 years respectively, had evidence of insulitis (Table 3 ). Thus, the 3 populations of islet described in the recent onset cases - insulin containing islets without insulitis, insulin containing islets with insulitis and insulin deficient islets - were all represented in patients with prolonged duration diabetes although obviously in quite different proportions.

\section{Distribution of insulin containing islets and insulitis within the pancreas}

Samples from both PP rich lobe and glucagon rich lobe were available in 15 cases, 8 of whom had disease of re- cent origin. One of these patients was under a year old and apparently had a normal pancreas; normal insulin containing islets were present in the PP lobe in this patient. Among the other patients, 9 of whom had insulin containing islets in the glucagon rich lobe, $\mathrm{B}$ cells were found in the PP lobe in only 1 patient (recent onset age 19 years) in which only one insulin containing islet was present. Insulitis was present in the glucagon rich lobe in 6 of the 15 patients but was not seen in the PP lobe.

The exocrine pancreas is divided into lobules which are separated from each other by connective tissue septa. The distribution of insulin containing islets and Bcell destruction, as witnessed by insulitis, did not appear to be entirely random, but there appeared to be a marked lobular distribution in many cases. Thus, in a given case, while the majority of lobules may have contained only insulin deficient islets, the insulin containing islets would be present in a small number of lobules in which few insulin deficient islets were present (Fig. 6). Similarly, islets affected by insulitis tended to be grouped together within individual lobules.

\section{Findings in the exocrine pancreas}

Focal acute pancreatitis was present in 6 cases ( 5 of recent onset). In addition to polymorphs in the interstitial tissue, polymorphs were also present in ducts in some cases. A diffuse lymphocytic infiltrate was present in 9 cases (4 of recent onset), and this made an assessment of the presence of insulitis impossible in these cases.

Exocrine acini surrounding insulin containing islets were larger and contained more zymogen granules than 

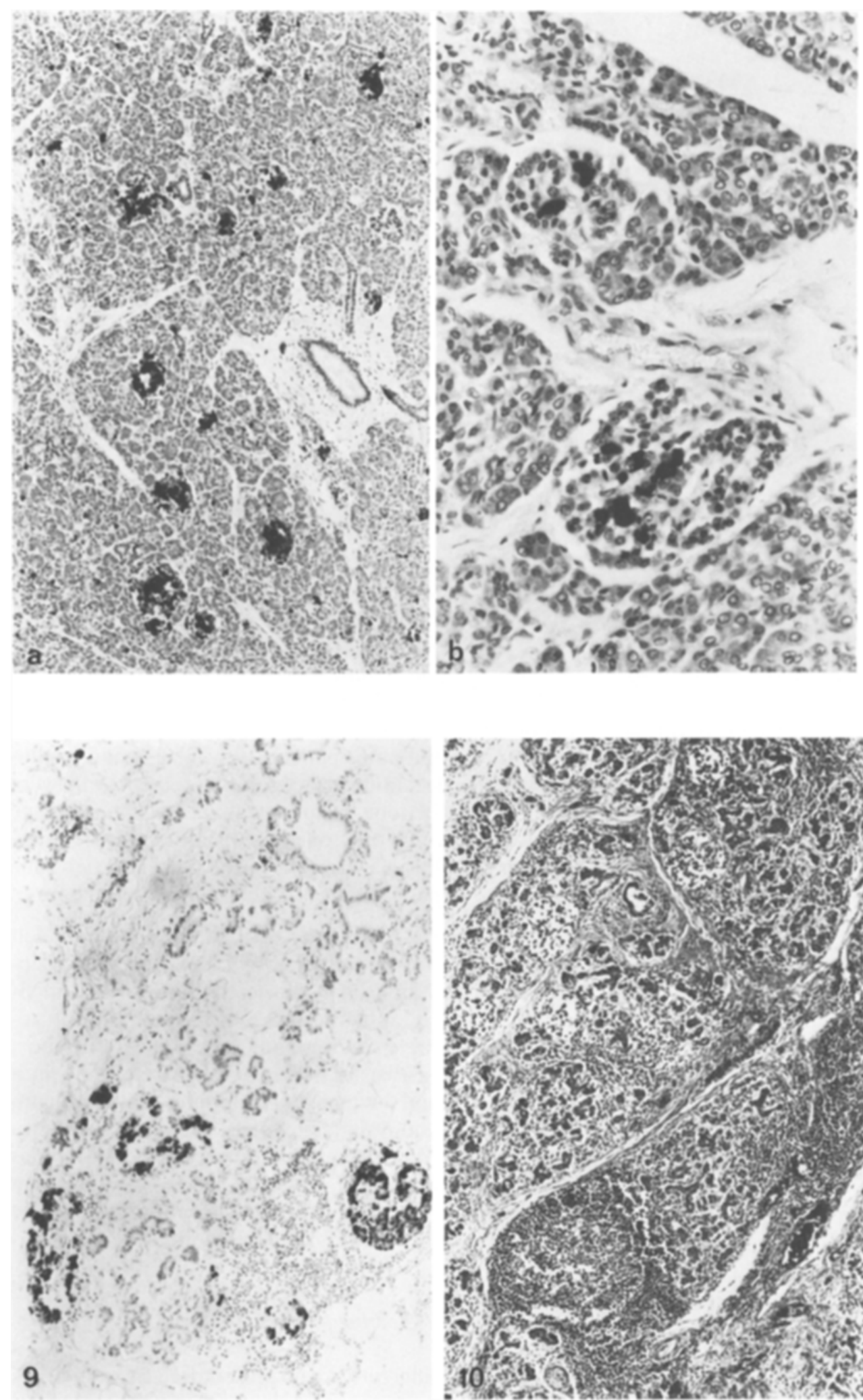

Fig. 8a and b. 13-month-old child who presented with neonatal diabetes and was treated with insulin. While in a it can be seen that all islets contained insulin, $b$ shows that some islets had reduced numbers of $B$ cells. Insulitis was not seen (indirect immunoperoxidase for insulin, $\times 80(a)$ and $\times 260(b))$
Fig.9. 17-year-old male with recent onset diabetes. Many exocrine lobules had disappeared and been replaced by fat. In addition to exocrine atrophy, this figure shows insulin containing islets affected by insulitis (indirect immunoperoxidase for insulin, $\times 100$ )

Fig. 10. 14-year-old patient with Down's syndrome, prolonged duration diabetes and steatorrhoea. All islets were insulin deficient. Note the marked diffuse chronic inflammatory infiltrate and exocrine atrophy (haematoxylin and eosin $\times 55$ ) acini surrounding insulin deficient islets. Acini from patients with prolonged duration diabetes tended to be small and zymogen depleted. In those cases where both PP lobe and glucagon rich lobe were included, the exocrine tissue in the two lobes appeared the same.

\section{Patients with atypical pancreatic pathology}

Having described the findings in the "classical" examples of Type 1 diabetes, it is necessary to highlight several cases which were radically different. 
There were 3 patients aged 18 months or less with recent onset diabetes in whom insulitis was not only absent, but whose islets were all insulin containing and appeared entirely normal (Fig.7). All presented with marked hyperglycaemia and coma. There was no clinical doubt about the diagnosis and the autopsy findings were consistent with a biochemical death. Another patient who possibly belonged to this group was a female, aged 13 months, who had presented with neonatal diabetes, had been treated with insulin for over a year and died of ketoacidosis. In her pancreas there appeared to be a normal number of islets; all contained insulin, although some islets appeared to have reduced numbers of $B$ cells and insulitis was absent.

The findings in one previously healthy 17 -year-old male with diabetic symptoms for less than a week were unique in this series. There was total exocrine atrophy of most lobules, and islets were aggregated in adipose tissue. However, some lobules of the pancreas had normal exocrine tissue and the ducts were normal. Superimposed upon this chronic exocrine condition were the typical features in the endocrine pancreas of recent onset diabetes - a mixture of insulin containing and insulin deficient islets with many of the former affected by insulitis (Fig.9). The possibility of Shwachman syndrome [7] was considered, but the patient had no haematological abnormalities, normal growth, no skeletal changes and no history of steatorrhoea.

One patient, a 14-year-old boy with Down's syndrome who had had diabetes for several years, also had steatorrhoea of unknown cause. In his pancreas there was an extremely dense, diffuse lymphocytic infiltrate with germinal centre formation; all islets were insulin deficient. The exocrine lobules were preserved but the acini were almost totally degranulated and atrophic (Fig.10). While there was a resemblance to cystic fibrosis, in this case the ducts and acini were not dilated, there were no ductal concretions and there was no pulmonary pathology.

\section{Patients with other clinical disorders}

Three patients had Down's syndrome. One is described above. Two had had diabetic symptoms for less than 2 weeks, one of whom presented at 18 months and had no morphological abnormality in the pancreas. The other presented at 12 years and had a pancreas more typical of recent onset diabetes (insulitis affecting insulin containing islets). The pancreatic histology in patients with other problems (autoimmune diseases, myocarditis, etc.) did not differ significantly from the remaining patients.

\section{Discussion}

Many of the pathological findings in the pancreas of patients with classical Type 1 diabetes, described in this paper, have been previously reported. The present study can confirm that insulin deficient islets form the majority of islets in most recent onset and almost all prolonged duration cases, but that surviving $B$ cells can still be found in Type 1 diabetes of prolonged duration $[1,8]$. The description given of insulin depleted islets and of the cells involved in the inflammatory infiltrate of insulitis does not differ substantially from other reports $[1,4$, $5,8]$. The non random, lobular distribution of residual insulin containing islets has previously been well illustrated [1]. The finding of zymogen depletion of exocrine acini around insulin deficient islets, when compared to acini around insulin containing islets, was the subject of a report which discussed the possible mechanisms involved at length [5].

There is more controversy in the literature concerning the frequency of insulitis in recent onset Type 1 diabetes. While Gepts [1] identified it in 15 out of 22 cases, Junker et al. [4] in 6 of 11 cases and Foulis and Stewart [5] in 8 of 9 cases, it was not seen in the 13 patients studied by Doniach and Morgan [3]. Junker et al. [4] suggested that the lesion was more frequent in younger patients; indeed, when the results of these studies are amalgamated, they show that 23 out of 30 patients aged 14 years and under had insulitis. By contrast, this lesion was seen in only 6 out of 25 patients older than 14 years. In the study by Doniach and Morgan [3], 5 of the 13 untreated diabetic patients studied were under 15 years of age, and two of them were thought to have only insulin deficient islets in the material examined. In Gepts' study [1] insulitis was not found in patients with diabetes of greater than 6 months duration. However, 4 of Doniach and Morgan's [3] 8 untreated diabetic patients aged 17 to 21 years at onset of diabetes had had diabetes for longer than 6 months at the time of death, and one of them was thought to have no residual insulin containing islets. These factors may have contributed to the absence of insulitis in their report.

In the present study, insulitis was found in 47 of the 60 patients (78\%) with known recent onset disease, and it confirms the high proportion of patients under 15 years of age with this lesion (Table 2). Only one block of pancreas was available for study in all 7 patients aged 15 to 19 years and in 2 of the 3 patients aged 10 to 14 years with recent onset diabetes in whom no evidence of insulitis was found. Since the distribution of insulitis within the pancreas is very patchy [1], there must be a serious risk of sampling error, particularly in an adult sized pancreas, if only one block of pancreas is available for study. This may well have contributed to the reduced incidence of insulitis in the older patients studied. Only prospective studies, in which multiple blocks of pancreas are available, can satisfactorly answer the question of whether insulitis is present more commonly in this age group than indicated by retrospective studies.

If insulitis is the pathognomonic lesion of Type 1 diabetes, what pathological process does it represent? Gepts and De May [8] studied 16 patients with recent 
onset Type 1 diabetes, 11 of whom had insulitis. In one case they noted that insulitis affected only islets containing B cells. This finding was observed in a higher number of cases by Foulis and Stewart [5], and has been put beyond doubt in the present study, which shows that insulin containing islets are 23 times more likely to be affected by this lesion than insulin deficient islets (Table 1). In a case report of recent onset Type 1 diabetes, the majority of infiltrating lymphocytes involved in insulitis were of T cytotoxic/suppressor phenotype [9]. Taken together, these findings support the concept that insulitis represents an immunologically mediated destruction of B cells [10].

The presence of complement fixing islet cell antibodies in the serum of patients several years before clinical presentation with Type 1 diabetes has suggested that B-cell destruction may take place during this time [11]. The present study has shown that B-cell destruction, as witnessed by insulitis, can be present up to 6 years after diagnosis, which is further evidence that the disease process in the pancreas can have a very protracted course.

Excluding a very young patient with no demonstrable pancreatic abnormality, insulin containing islets were virtually never seen in the PP lobe, and insulitis was not observed. The same phenomenon was documented in a detailed case report of a 9-year-old girl dying of recent onset Type 1 diabetes [12].

While acknowledging that normal PP islets contain fewer B cells than islets in the glucagon rich lobe, the relative increase in amount of endocrine tissue compared to exocrine tissue in the PP lobe means that the number of $\mathrm{B}$ cells per unit volume of the PP lobe is only reduced by approximately $50 \%$ when compared to the glucagon rich lobe [13]. It is not thought that this is sufficient to explain the virtual absence of B cells from the PP lobe in recent onset Type 1 diabetes. This, plus the lack of insulitis, suggests that destruction of B cells in the PP lobe is completed sooner than in the glucagon rich lobe.

Three children with recent onset disease, aged 18 months or less, had no insulitis and apparently normal numbers of islets with a normal proportion of B cells. Since there seemed little doubt clinically that these children had diabetes, it has to be suggested that they may have had a different disease from the classical Type 1 diabetes which is accompanied at presentation by loss of B cells. The child with neonatal diabetes who died at age 13 months and who had required insulin therapy during this time may also belong to this pathogenetic group. It is not meant to be implied that all children who present with diabetes at age less than 2 years have a different disease. There were 8 patients in the present survey with diabetes of prolonged duration who had presented under 2 years of age. At the time of death all islets were insulin deficient in these patients. There has been a previous case report of a diabetic patient who presented at age 8 years, had no evidence of insulin deficient islets at autopsy and died at the age of 22 years of diabetic nephropathy [14]. All islets contained insulin and, indeed, there was striking hyperplasia of B cells. While this case serves to highlight the heterogeneity of diabetes occurring in childhood, the B cell hyperplasia and age of onset suggest that the pathogenesis of this case may be different from that of the four patients discussed above.

Acknowledgements. Sincere thanks are extended to the many pathologists who allowed their material to be studied. The help of Dr. R.J.Webb of the Scottish Health Service Common Services Agency and Dr. M.R. Alderson of the Office of Population Censuses and Surveys is also acknowledged. The monoclonal antibody PD7/26 was gifted by Dr. D.Y.Mason (Oxford). This study was financed by the Research Support Group of the Greater Glasgow Health Board.

\section{References}

1. Gepts W (1965) Pathologic anatomy of the pancreas in juvenile diabetes mellitus. Diabetes 14:619-33

2. Maclean N, Ogilvie RF (1959) Observations on the pancreatic islet tissue of young diabetic subjects. Diabetes 8: 83-91

3. Doniach I, Morgan AG (1973) Islets of Langerhans in juvenile diabetes mellitus. Clinical Endocrinology 2: 233-248

4. Junker K, Egeberg J, Kromann H, Nerup J (1977) An autopsy study of the islets of Langerhans in acute-onset juvenile diabetes mellitus. Acta Path Microbiol Scand Sect A 85: 699-706

5. Foulis AK, Stewart JA (1984) The pancreas in recent-onset Type 1 (insulin-dependent) diabetes mellitus: insulin content of islets, insulitis and associated changes in the exocrine acinar tissue. Diabetologia 26: 456-461

6. Warnke RA, Gatter KC, Falini B, Hildreth P, Woolston RE, Pulford K, Cordell JL, Cohen B, DeWolf-Peters C, Mason DY (1983) Diagnosis of human lymphoma with monoclonal antileukocyte antibodies. New Engl J Med 309: 1275-81

7. Shwachman H, Diamond LK, Oski FA, Khan K (1964) The syndrome of pancreatic insufficiency and bone marrow dysfunction. J Paediatr 65: 645-663

8. Gepts W, De Mey J (1978) Islet cell survival determined by morphology. An immunocytochemical study of the islets of Langerhans in juvenile diabetes mellitus. Diabetes 27 (Suppl 1): 251-261

9. Bottazzo GF, Dean BM, McNally JM, MacKay EH, Swift PGF, Gamble DR (1985) In situ characterization of autoimmune phenomena and expression of HLA molecules in the pancreas in diabetic insulitis. New Engl J Med 313: 353-360

10. Bottazzo GF (1984) Beta cell damage in diabetic insulitis: are we approaching a solution? Diabetologia 26: 241-249

11. Gorsuch AN, Spencer KM, Lister J, McNally JM, Dean BM, Bottazzo GF, Cudworth AG (1981) Evidence for a long prediabetic period in Type 1 (insulin-dependent) diabetes mellitus. Lancet 2: $1363-5$

12. Klöppel G, Drenck CR, Oberholzer M, Heitz PU (1984) Morphometric evidence for a striking B-cell reduction at the clinical onset of Type 1 diabetes. Virchows Arch (Pathol Anat) 403: 441-452

13. Stefan Y, Orci L, Malaisse-Lagae F, Perrelet A, Patel Y, Unger RH (1982) Quantitation of endocrine cell content in the pancreas of non-diabetic and diabetic humans. Diabetes 31: 694-700

14. Evans DJ (1972) Generalized islet hypertrophy and beta-cell hyperplasia in a case of long-term juvenile diabetes. Diabetes 21: 114-116

Received: 10 October 1985

and in revised form: 3 March 1986

Dr. A. K. Foulis

Department of Pathology

Royal Infirmary

Glasgow, G4 OSF

UK. 